\title{
Preliminary Study for Design Core of Nuclear Research Reactor of TRIGA Bandung Using Fuel Element Plate MTR
}

\author{
Anwar Ilmar Ramadhan ${ }^{1,3, *}$, Aryadi Suwono ${ }^{1}$, Efrizon Umar ${ }^{2}$, \\ and Nathanael Panagung Tandian ${ }^{1}$ \\ 1 Energy Conversion, Thermodynamics Lab, Faculty of Mechanical and Aerospace Engineering, \\ Institut Teknologi Bandung, Indonesia \\ 2 Center for Applied Nuclear Science and Technology, National Nuclear Energy Agency of Indonesia, \\ Indonesia \\ 3 Department of Mechanical Engineering, Faculty of Engineering, Universitas Muhammadiyah Jakarta, \\ Indonesia \\ *E-mail: airamadhan@students.itb.ac.id (Corresponding author)
}

\begin{abstract}
The nuclear reactor has two types of power reactors based on the function that is used as electrical energy and research reactors and radioisotope used as a producer of nuclear science and technology research. Indonesia has three research reactors are two types of TRIGA research reactor in Bandung with a power of $2 \mathrm{MW}$ and in Yogyakarta with a power of $100 \mathrm{~kW}$ and a research reactor in PUSPIPTEK Serpong with nominal power of $30 \mathrm{MW}$. For the second fuel elements TRIGA type reactor that is currently using elements of cylindrical material, while the fuel elements RSG-GAS reactor in Serpong-shaped plate. Reactor TRIGA Bandung is a reactor that can be used to predict the buffer reactor. However, this reactor has a problem because of the limited number of existing fuel element. Meanwhile, production of TRIGA fuel elements abroad already closed. Given that Indonesia has the ability to produce nuclear fuel elements for research reactors fueled plate it is proposed to modify the reactor core of TRIGA Bandung of the terrace patio made from a cylinder into fuel plates. In this research will be studied more deeply about aspects thermal-hydraulics TRIGA research reactor using fuel elements plate replacement to cylinder fuel element. The method used is the modeling and simulation of the fuel element plate using porous media and non-porous media with the program of CFD Code. Results of the simulation show that the phenomenon of flow and temperature distribution closer to the comparison of the design elements used fuel plate. So later this plate fuel elements can be used in a nuclear reactor core TRIGA research Bandung, Indonesia.
\end{abstract}

Keywords: Research reactor, fuel element plate MTR, CFD, TRIGA, porous media.

ENGINEERING JOURNAL Volume 21 Issue 3

Received 14 June 2016

Accepted 17 October 2016

Published 15 June 2017

Online at http://www.engj.org/

DOI:10.4186/ej.2017.21.3.173 


\section{Introduction}

The nuclear reactor has two types of power reactors based on the function that is used as electrical energy and research reactors and radioisotope used as a producer of nuclear science and technology research. Indonesia has three research reactors are two types of TRIGA research reactor in Bandung with a power of $2 \mathrm{MW}$ and in Yogyakarta with a power of $100 \mathrm{~kW}$ and a research reactor in Serpong Puspiptek nominal power of $30 \mathrm{MW}$. For the second fuel elements TRIGA type reactor that is currently using elements of cylindrical material, while the fuel elements RSG-GAS reactor in Serpong shaped plate [1-3].

These three research nuclear reactors owned by Indonesia used for research, radioisotope production and training related to nuclear science and technology. The third reactor was aged over 25 years. For the production of radioisotopes, RSG-GAS reactor in Serpong Puspiptek play a major role, both to supply the needs of the country and the ASEAN region [4-6]. Nevertheless, these reactors in the near future will undergo thorough maintenance that is required buffer reactors for the production of radioisotopes, mainly for domestic needs.

Bandung TRIGA reactor is a reactor that can be used to predict the buffer reactor. However, this reactor has a problem because of the limited number of existing fuel element. Meanwhile, production of TRIGA fuel elements abroad already closed. Given that Indonesia has the ability to produce nuclear fuel elements for research reactors fueled plate it is proposed to modify the Bandung TRIGA reactor core of terraces made from the cylinder into the porch fueled plate [7-8].

In this research include the design of the reactor core or the cooling system for the reactor power accordingly. TRIGA research reactor core modification of the fuel cylinders into fuel plates according to fuel domestic production, this has never been done. It is also expected the reactor core design is engineered by his own nation, so that the independence of the research reactor core design and fuel element can be realized (Fig. 1).

Heat and mass transfer methods that can be analyzed further using several methods, one of the approaches used in the fuel element plate is a method of porous media [9]. In this research, modeling and simulation of the fuel element plate as a whole compared with the previous research, and modeling at the TRIGA research reactor core using the fuel element plate by comparing methods of porous media and without porous media.

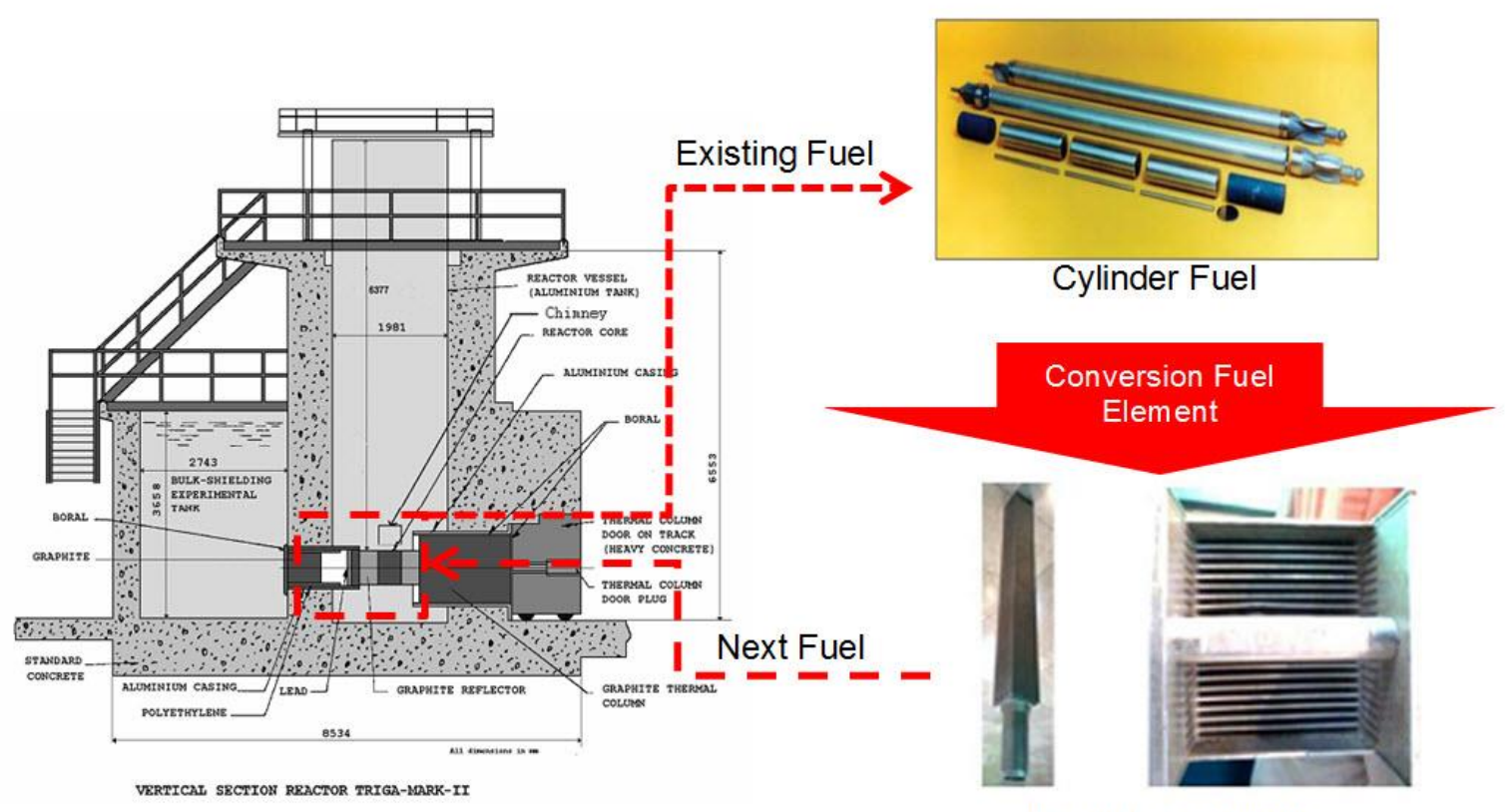

Fuel Element MTR

Fig. 1. Modification of Research Reactor TRIGA Bandung With Fuel Element Plat MTR. 


\section{Research Method}

\section{Modeling of Fuel Element Plate MTR}

Modeling done using Computer Aided Design Code, a model created by the three-dimensional picture of the fuel plates were cut in half, this is done with consideration of the symmetric model form and also alleviate the performance of computers with limited Random Access Memory (RAM). Dimensional model using the reference of RSG GAS fuel elements (Table 1) and the modeling results can be seen in Fig. 2.

Table 1. Design data of plate fuel element MTR [6].

\begin{tabular}{l|c}
\hline \multicolumn{2}{c}{ Mechanical Design Parameter Fuel Element Plat } \\
\hline Fuel Element & $\mathrm{RI}$ \\
\hline Type & 21 \\
\hline Number plate in the standard fuel element & \\
\hline Fuel Element Plate MTR & 960 \\
\hline The amount of fuel in the core plate & 0.54 \\
\hline The Thickness of the zone of meat, $\mathrm{mm}$ & 62.75 \\
\hline The Width of zone meat, $\mathrm{mm}$ & 600 \\
\hline The Length of zone meat, $\mathrm{mm}$ & $\mathrm{U}_{3} \mathrm{Si}_{2}-\mathrm{Al}$ \\
\hline Type of Fuel Element & 19.75 \\
\hline Enrichment, $\%$ & 2.96 \\
\hline The density of uranium in meat, $\mathrm{g} / \mathrm{cm}^{3}$ & 0.38 \\
\hline The thickness of cladding, $\mathrm{mm}($ average $)$ & 0.25 \\
\hline The thickness of cladding, $\mathrm{mm}(\mathrm{minimum})$ & $\mathrm{AlMg}_{2}$ \\
\hline Cladding material design & 1.3 \\
\hline Plate thickness fuel, $\mathrm{mm}$ & 70.75 \\
\hline The width of fuel plates, $\mathrm{mm}$ & 625 \\
\hline The Length of fuel plates, $\mathrm{mm}$ &
\end{tabular}

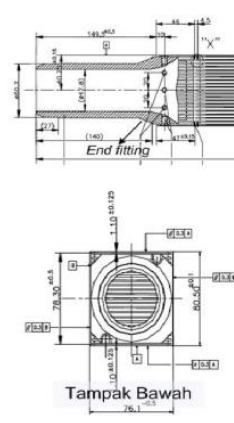

(a) Design of Fuel Element Plate MTR

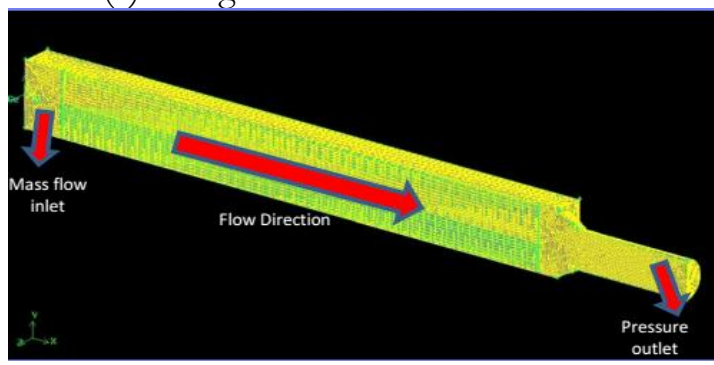

(d) Boundary of Modeling

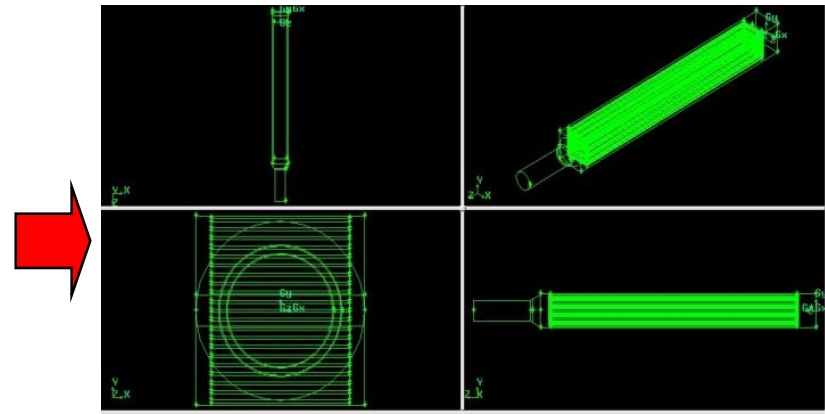

(b) Modeling of Fuel Element Plate

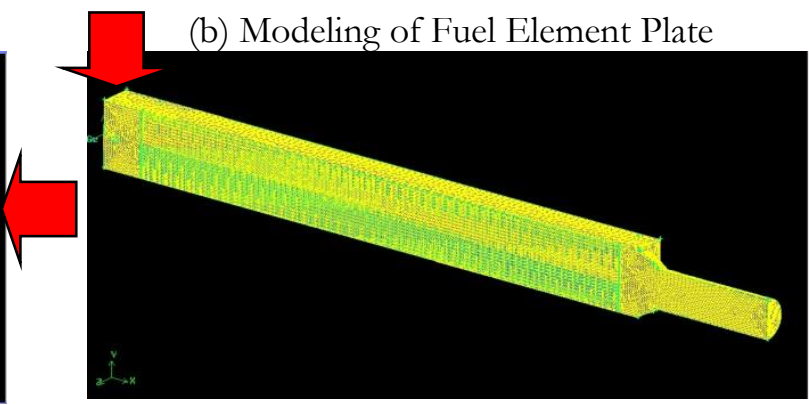

(c) Meshing of Modeling

Fig. 2. Modeling of fuel element plate MTR. 


\section{Meshing}

Once that was done to make the process of meshing the model discretization, this process will determine the level of accuracy in the simulation process, the greater the value discretization volume will make simulation results more accurate. But, given the limited computer capabilities, so look for the value of rational volume discretization. Meshing is done by using elements tetrahedral; meshing results can be seen in Fig. 2 and discretization models produce 375034 tetrahedral cells.

The results of the process of meshing the checking process is then performed using the CAD feature mesh examine Code. In this feature mesh checked for quality by EquiSize Skew tolerance limit should be no more than 0.97. If EquiSize Skew is greater than the value it should be re-meshing. The results show the quality checking of mesh mesh 0.9625 or less than 0.97 so it can be stated that the quality of a good mesh. Furthermore, the determination of the boundary, the boundary consists of input, output, walls and symmetry. Input type is defined by the inlet mass flow, then the output is defined by the outlet pressure, the wall is defined by the wall and symmetry.

Simulations carried out by using Computational Fluid Dynamics (CFD) Code using modeling that is already defined in the software CAD. From the data that has been created in CAD Code, is then defined in more detail by specifying the limit value. The boundary conditions in CFD code with the parameters set flow rate of $12.5 \mathrm{~kg} / \mathrm{s}$ and a temperature of $40.5^{\circ} \mathrm{C}$ then heatflux the fuel element of $41.5 \mathrm{~W} / \mathrm{cm} 2[6]$. As in Table 2.

Table 2. Parameters boundary conditions [6].

\begin{tabular}{lc}
\hline \multicolumn{1}{c}{ Boundary Type } & Value \\
\hline Mass flow Inlet $(\mathrm{kg} / \mathrm{s})$ & 12.5 \\
Fluid Inlet of Temperature $\left({ }^{\circ} \mathrm{C}\right)$ & 40.5 \\
Heat Flux $\left(\mathrm{W} / \mathrm{cm}^{2}\right)$ & 41.5 \\
Pressure outlet $(\mathrm{kPa})$ & 200 \\
\hline
\end{tabular}

\section{Results and Disscussion}

\section{Temperature Distribution of Fuel Element MTR}

The results of numerical simulation of fuel element plate carried by the approach porous media and nonporous media with the help of CFD Code can then be analyzed further to the distribution of temperature and flow rate compared to the results of previous research by Subekti, 2013. The temperature distribution in the fuel element plate MTR which have been simulated with CFD Code can be seen in Figs. 3-5.

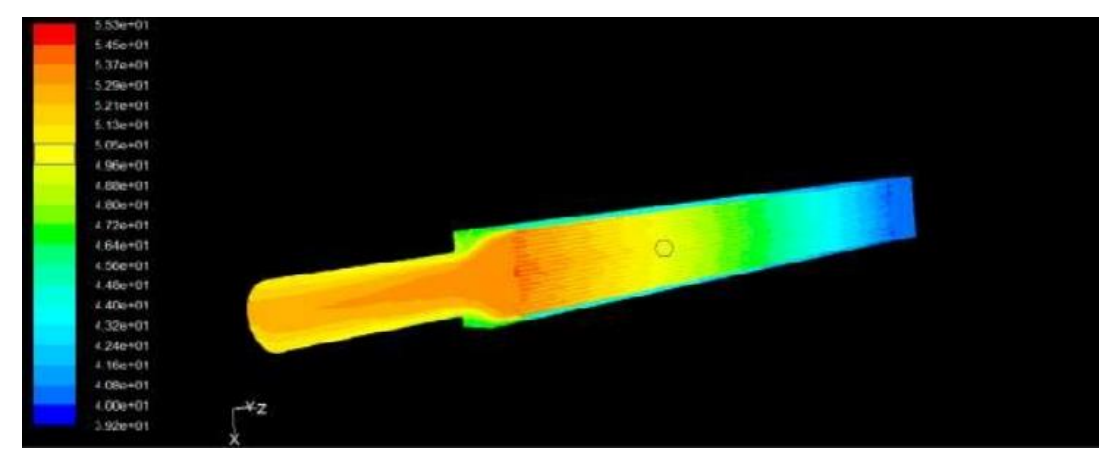

Fig. 3. Distribution of temperature for fuel element MTR use non porous media. 


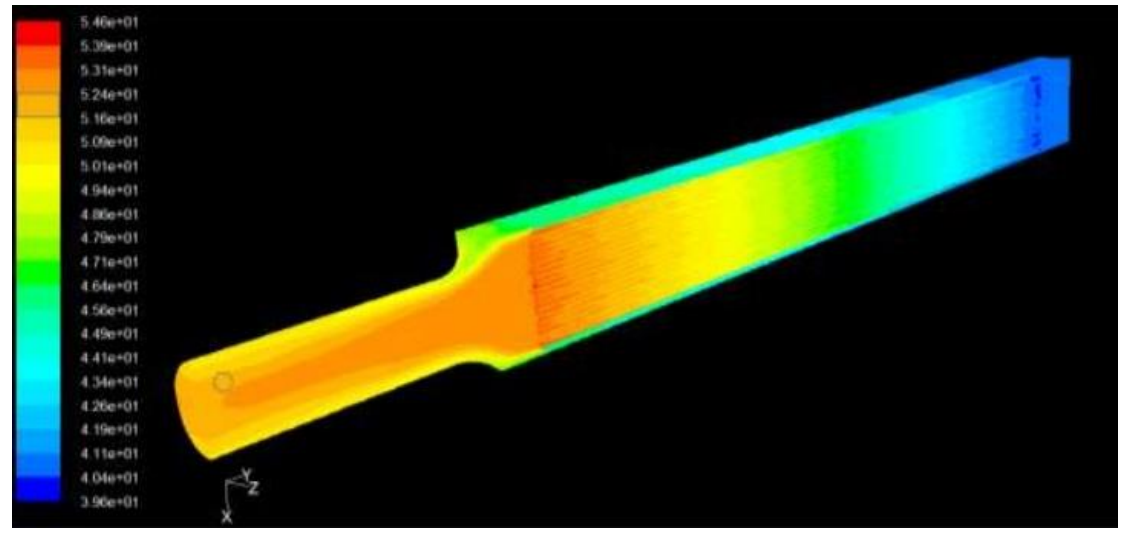

Fig. 4. Distribution of temperature for fuel element MTR use porous media.

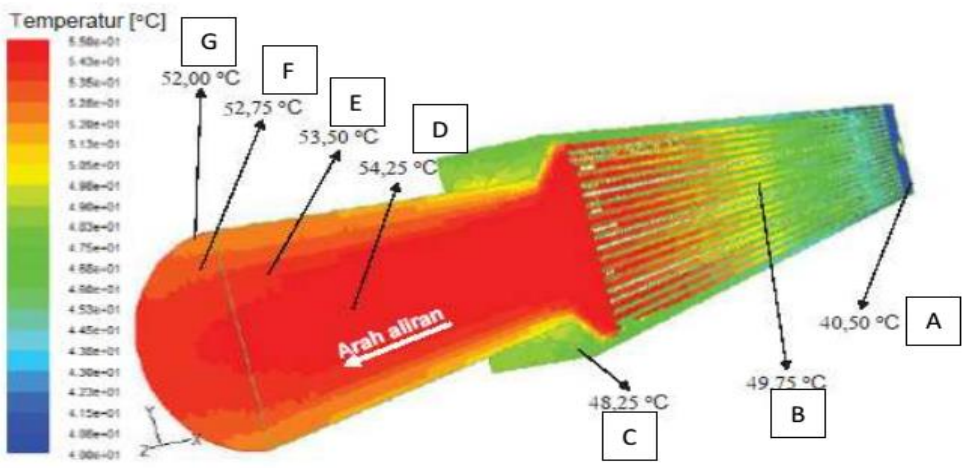

Fig. 5. Distribution of temperature for fuel element MTR [10].

Figures 3 to 5 have a distribution pattern is almost the same temperature, the low temperature fluid flow towards the entry area into fuel elements and temperature increases at the threshold of discharge fluid flow of fuel element plate. Figure 3 is a numerical simulation results fuel element plate with a non-porous media has a value of temperatures: $50.5^{\circ} \mathrm{C}, 53.3^{\circ} \mathrm{C}$ and $50.9^{\circ} \mathrm{C}$, while Fig. 4 is numerical results fuel element plate by the method of porous media to each location is $49.75^{\circ} \mathrm{C}, 52.75^{\circ} \mathrm{C}$ and $50.5^{\circ} \mathrm{C}$. Figure 5 is the result of numerical calculations have been done by Subekti, 2013 i.e. $49.75^{\circ} \mathrm{C}, 54.25^{\circ} \mathrm{C}$ and $52.0^{\circ} \mathrm{C}$.

Comparison data of temperature distribution on the plate with the fuel element method porous and non-porous media than the media and the research that has been done by Subekti, 2013 can be seen in Table 3, and the graph of temperature distribution comparison in Fig. 6.

Table 3. Comparison of temperature distribution.

\begin{tabular}{cccc}
\hline Position & Porous media $\left({ }^{\circ} \mathbf{C}\right)$ & Non porous media $\left({ }^{\circ} \mathbf{C}\right)$ & Subekti $(\mathbf{2 0 1 3})[\mathbf{1 0}]\left({ }^{\circ} \mathbf{C}\right)$ \\
\hline A & 40.5 & 40.5 & 40.5 \\
B & 49.75 & 50.05 & 49.75 \\
C & 47.5 & 47.6 & 48.25 \\
D & 52.75 & 53.3 & 54.25 \\
E & 52.0 & 52.5 & 53.5 \\
F & 51.25 & 51.7 & 52.75 \\
G & 50.5 & 50.9 & 52.00 \\
\hline
\end{tabular}




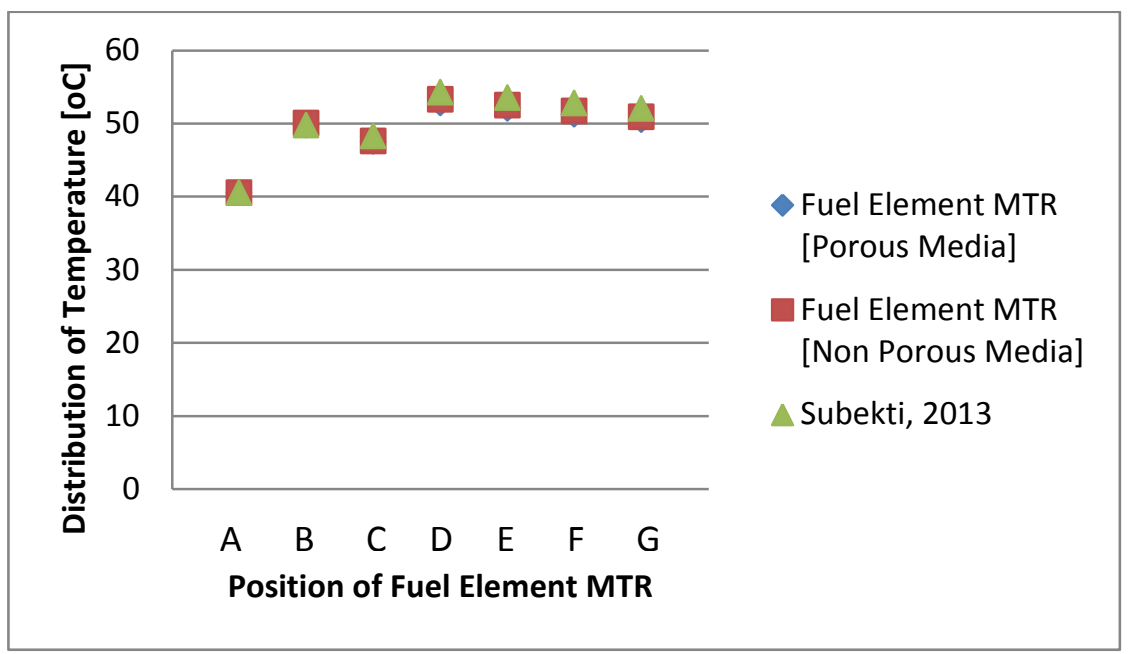

Fig. 6. Comparison of temperature distribution between researched by Subekti (2013) [10].

Figure 6 shows a comparison temperature distribution of each method used is porous and non-porous media and the media compared to the previous study by Subekti, 2013. It appears that for the deployment temperature has almost the same pattern, i.e. the beginning of the entry of the fluid into the fuel element is not cause a rise in temperature which means that, after the temperature gradually increased in the direction of the $\mathrm{x}$-axis to the regional output of the fuel element plate. Regions with large temperature were in the location $\mathrm{D}$ in the vicinity of the output of the fuel element plate. And, an area that has a lower temperature values are in location $A$, the area of the input of the fluid.

\section{Velocity Flow Distribution}

Furthermore, after knowing the phenomenon of the spread of the temperature on the plate fuel element, it can be analyzed more about the phenomenon of the spread of the flow rate that occurred in the fuel element plate use method porous and non-porous media can be seen in Figs. 7-9.

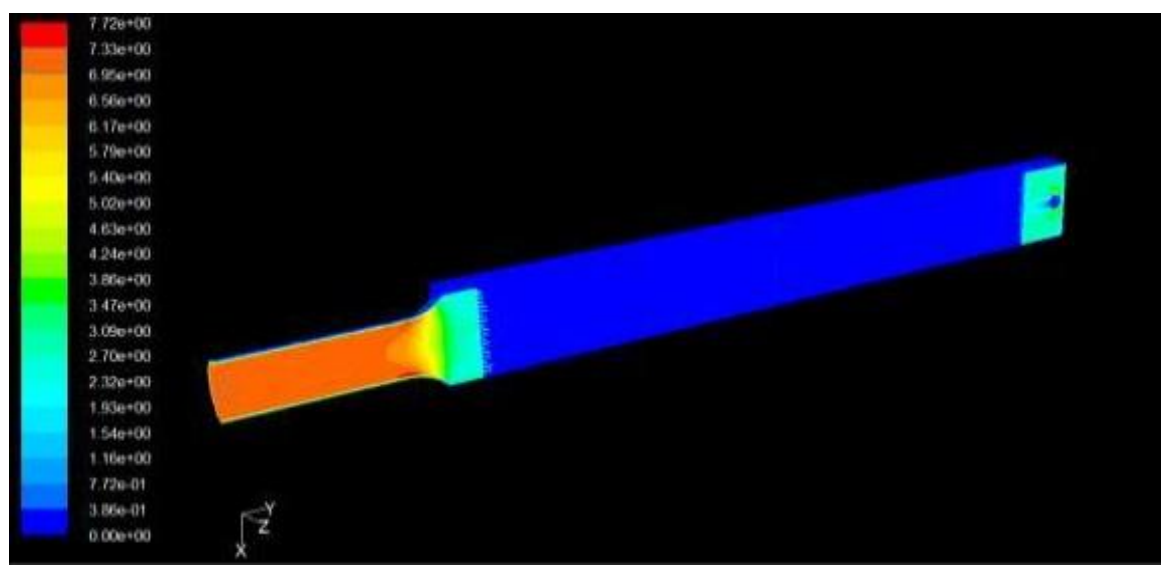

Fig. 7. Distribution of velocity flow of fuel element MTR use non porous media. 


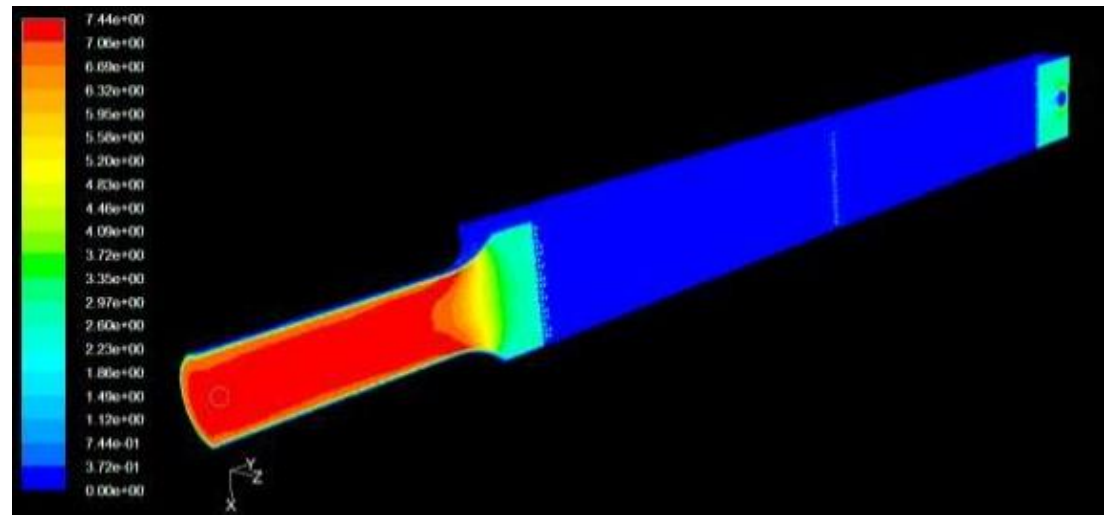

Fig. 8. Distribution of velocity flow of fuel element MTR use porous media.

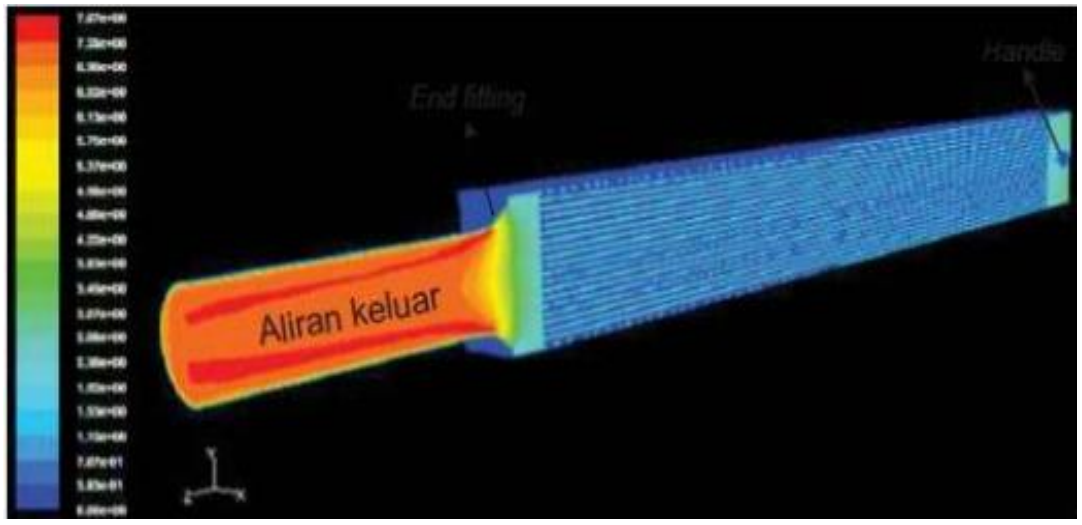

Fig. 9. Distribution of velocity flow of fuel element MTR [10].

Figures 7-9 show the pattern of spread of fluid flow velocity in the fuel element plate is almost the same, i.e. the beginning of the entry of the fluid in the fuel element plate MTR still low marked in blue, then increase marked in red until at the end of the exit of the fuel element. Figure 7 explains that the fuel element plate MTR simulated with CFD Code using a non-porous media has a spread pattern of the flow velocity at the position over the fuel by $3.67 \mathrm{~m} / \mathrm{s}$, the area of end fittings at $5.59 \mathrm{~m} / \mathrm{s}$ and the pipe outer element fuel $7.14 \mathrm{~m} / \mathrm{s}$. Figure 8 shows the pattern of spread of the flow velocity in the fuel element plate MTR by using porous media have spread of speed in the gap of fuel $3.62 \mathrm{~m} / \mathrm{s}$, end fittings amounted to $5.76 \mathrm{~m} / \mathrm{s}$ and the area of pipe outer fuel elements at $7.25 \mathrm{~m} / \mathrm{s}$.

While Fig. 9 describes the pattern of spread of the flow rate that has been done by Subekti, 2013, the which is to slit the fuel are velocity flow of $3.66 \mathrm{~m} / \mathrm{s}$, end fittings amounted to $5.93 \mathrm{~m} / \mathrm{s}$ and the pipeline output of $7.67 \mathrm{~m} / \mathrm{s}$. Differences of numerical simulation results of each method shows differences not significant because this approach aims to complement and validate the models MTR fuel element plate that will be used later in the core reactor TRIGA Bandung in Indonesia. The results of the deployment pattern of flow velocity in the plate MTR fuel elements can be seen in Table 4. And, a graph comparison of the distribution of the flow rate of each method, the method of porous and non-porous media and media research conducted by Subekti, 2013 can be seen in Fig. 10.

Table 4. Comparison of the phenomenon of the flow velocity in the fuel element plate MTR.

\begin{tabular}{l|c|c|c}
\hline Flow Position & $\begin{array}{l}\text { Porous } \\
\text { media }\end{array}$ & $\begin{array}{l}\text { Non porous } \\
\text { media }\end{array}$ & Subekti, 2013 \\
\hline Cracks fuel m/s & 3.62 & 3.67 & 3.66 \\
Under slit fuel m/s & 2.78 & 2.51 & 2.76 \\
End- fitting m/s & 5.76 & 5.59 & 5.93 \\
Pipe outer fuel elements m/s & 7.25 & 7.14 & 7.67 \\
\hline
\end{tabular}




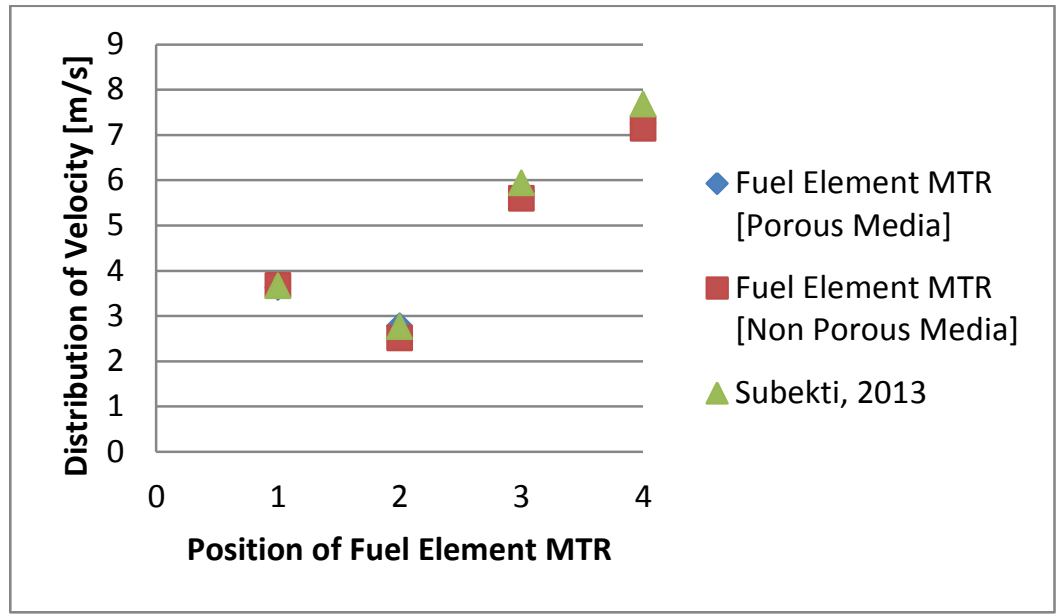

Fig. 10. Comparison of the velocity distribution.

Figure 10 shows the comparison of the distribution of the flow rate of each method used is porous and non-porous media and the media compared to the previous study by Subekti, 2013. It appears that the pattern of spread of the flow rate is almost the same in all the methods used, has a low speed at the beginning of the entry of the fluid into the fuel element plate, then increase the flow rate until the tip of the pipe output fuel element plate MTR. This is due to the narrowing of the dimensions of the model fuel element plate. The pattern of the spread flow rates are lowest in the No. 2 position is below the slit of fuel, and high flow velocities occur at the location No. 4 among pipe output fuel element plate MTR.

\section{Conclusions}

These results provide the follow conclusions are:

a. Wall temperature distribution that occurs in the fuel element plate showed a trend of rising in the middle position, and then decreased at the start position and end position fuel element plate.

b. The pattern of coolant flow rate has almost the same pattern for each model (porous and nonporous media), for the upstream position has a value of low speed, at a position downstream flow increased flow velocity due to narrowing.

\section{Acknowledgement}

This research was supported by National Nuclear Energy Agency of Indonesia (BATAN) and Ministry of Research, Technology, and High Education Republic of Indonesia.

\section{References}

[1] G. A. Mandala, "Modification simulation of reactor TRIGA 2000 Bandung with fuel element type plate," presented at National Seminar VI of Nuclear Technology of HRD, Yogyakarta, 2010.

[2] L. Suparlina, "Design study of research nuclear reactor core configuration for new research nuclear reactor in Indonesia," in Proceeding of Meeting and Scientific Presentations-Basic Research Nuclear Science and Technology in 2011, Yogyakarta.

[3] K. Kamajaya, P. R. Henky, and P. Ilham Yazid, "The Current Status of Bandung TRIGA Mark-II Reactor-Indonesia," in Pacific Basin Nuclear Conference, 2006, Australian Nuclear Association, p. 1056.

[4] P. Basuki, et al., "Conversion neutronic design of fuel element plate on core of TRIGA 2000 Bandung," Journal of Nuclear Science and Technology Indonesia, vol. 15, no. 2, pp. 69-80, 2014.

[5] H. Raflis, "Aspects of the study thermal-hydraulics of research reactor TRIGA 2000 for steady state condition (steady state) on some power operations," in Proceedings of the National Seminar - 17 NPP Safety Technology and Nuclear Facilities, Yogyakarta, 2011 
[6] M. Martínez-Lianes, R. Miró, P.A. L. Reis, C. Pereira, A. L. Costa, A. Z. Mesquita, S. Chiva, and G. Verdú, "Steady-state modeling of flow conditions of a TRIGA reactor using the CFD code ANSYS CFX," in Proc. International Nuclear Atlantic Conference, 2011.

[7] S. U. D. Khan, M. Peng, L. Li, and S. U. D. Khan, "Modification and validation of theatre code for the plate type fuel nuclear reactor," Annals of Nuclear Energy, vol. 53, pp. 519-528, 2013.

[8] A. Mesquita, D. A. Palma, A. L. Costa, C. Pereira, M. A. Veloso, and P. A. Reis, "Experimental distribution of coolant in the IPR-R1 TRIGA nuclear reactor core," in Proc. International Nuclear Atlantic Conference, 2011, pp. 978-985.

[9] Y. Yan and Rizwan-uddin, "CFD simulation of a research reactor," in Proceeding of Mathematics and Computation, Supercomputing, Reactor Physics and Nuclear and Biological Applications, France, 2005.

[10] M. Subekti, D. Isnaini, E. P. Hastuti, "Analysis of velocity coolant on fuel element plate using CFD method for RSG GAS research nuclear reactor," Journal of Nuclear Reactor Technology, vol. 15, no. 2, pp. 67-76, 2013. 